Jurnal Pendidikan Matematika : Judika Education

Volume 1, Nomor 1, Januari-Juni 2018

e-ISSN : 2614-6088

p-ISSN : 2620-732X

DOI: https://doi.org/10.31539/judika.v1i1.235

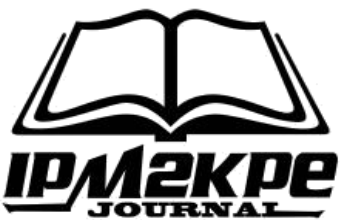

\title{
MODEL ELABORASI KOGNITIF SISWA DALAM PROSES ABSTRAKSI PRINSIP DAN KONSEP MATEMATIKA RUANG DIMENSI DUA DI KELAS XI TEKNIK LAS SMKN 1 CURUP
}

\author{
Novianti Mandasari \\ STKIP PGRI Lubuklinggau \\ noviantimandasari10@gmail.com
}

\begin{abstract}
ABSTRAK
Penelitian ini bertujuan untuk mendeskripsikan model elaborasi kognitif siswa dalam proses abstraksi konsep dan prinsip matematika ruang dimensi dua di Kelas XI Teknik Las SMKN 1 Curup. Penelitian ini menggunakan pendekatan kualitatif. Instrumen utama adalah peneliti sendiri dipandu dengan lembar tes kemampuan siswa dan lembar pedoman wawancara. Data dianalisis melalui tiga tahap, yaitu tahap reduksi data, penyajian data dan penarikan kesimpulan. Hasil penelitian; deskripsi model elaborasi siswa dalam proses abstraksi konsep matematika ruang dimensi dua: Model Recognizing; Siswa mengenal dengan jelas bangun-bangun ruang dimensi dua, Siswa dapat memahami definisi bangun ruang dimensi dua objek-objek ruang dimensi dua yang diberikan, dan berdasarkan informasi yang telah siswa peroleh sebelumnya. Siswa dapat menentukan objek-objek yang merupakan bangun ruang dimensi dua. Siswa dapat menemukan prinsip dari bangun ruang dimensi dua Model Building With; Siswa dapat menemukan hubungan-hubungan konsep dan prinsip dari bangun ruang dimensi dua dengan menganalisis gambar objek-objek bangun ruang dimensi dua. Model Contracting; Siswa mengetahui konsep-konsep apa yang akan digunakan, dan untuk mengetahui konsep tersebut siswa membayangkan dan membuat sketsa objek ruang dimensi dua dari permasalahan yang ada, dalam menyelesaikan permasalahan tersebut berhubungan dengan penggabungan prinsipprinsip matematika yang ada dalam konsep tersebut, dan pengetahuan siswa tersebut sesuai dengan kemampuan siswa mengingat. Simpulan, melalui konsep elaborasi kognitif dalam proses abstraksi prinsip dan konsep matematika ruang dimensi dua siswa mampu menggunakan konsep dan prinsip matematika dalam menyelesaikan permasalahan sehingga siswa mampu membuat kesimpulan dari hasil penyelesaian tersebut dan Siswa mampu menjelaskan atau memperesentasikan hasil pekerjaannya.
\end{abstract}

Kata Kunci: Konsep dan Prinsip Matematika, Model elaborasi Kognitif, Proses Abstraksi.

ABSTRACT

This study aims to describe the cognitive elaboration models of students in the process of abstraction of concepts and principles of two-dimensional mathematical space in Class XI of Las Teknik SMK 1 Curup. This research uses a qualitative approach. The main instrument is the researchers themselves guided by student 
ability test sheets and interview guide sheets. Data were analyzed through three stages, namely the stage of data reduction, data presentation and drawing conclusions. Research result; description of students' elaboration models in the process of abstraction of mathematical concepts in two-dimensional space: Recognizing models; Students are clearly familiar with the shapes of two-dimensional spaces, Students can understand the definition of two-dimensional shapes of twodimensional space objects given, and based on information that students have obtained previously. Students can determine the objects that constitute the building of two-dimensional space. Students can discover the principles of building a twodimensional space Model Building With; Students can discover the relationships of concepts and principles of two-dimensional geometric shapes by analyzing images of two-dimensional geometric objects. Model Contracting; Students know what concepts will be used, and to know these concepts students imagine and sketch a twodimensional space object of the existing problems, in solving these problems associated with the incorporation of mathematical principles contained in the concept, and the student's knowledge according to students' ability to remember. Conclusion, through the concept of cognitive elaboration in the process of abstraction of principles and mathematical concepts of two-dimensional space students are able to use mathematical concepts and principles in solving problems so students are able to make conclusions from the results of the settlement and students are able to explain or present the results of their work.

Keywords: Mathematical Concepts and Principles, Cognitive Elaboration Models, Abstraction Processes.

\section{PENDAHULUAN}

Pendidikan adalah upaya dasar yang dilakukan agar peserta didik atau siswa dapat mencapai tujuan tertentu. Agar siswa dapat mencapai tujuan pendidikan yang telah dilakukan, maka diperlukan wahana yang dapat dijadikan sebagai sarana penghubung. Pembelajaran matematika merupakan kegiatan pendidikan yang menggunakan matematika sebagai sarana untuk mencapai tujuan pendidikan yang ditetapkan. Guru matematika akan mampu menggunakan matematika untuk membawa siswa menuju tujuan yang ditetapkan, bila ia memahami dengan baik matematika yang akan digunakan sebagai wahana.

Matematika sebagai wahana pendidikan tidak hanya dapat digunakan untuk mencapai satu tujuan, misalnya mencerdaskan siswa, tetapi dapat pula untuk membentuk kepribadian siswa serta mengembangkan keterampilan tertentu. Hal itu mengarahkan perhatian kepada pembelajaran nilai-nilai dalam kehidupan melalui matematika (Soedjadi, 2000).

Matematika merupakan ilmu universal yang mendasari 
perkembangan teknologi modern, mempunyai peranan penting dalam ketajaman berpikir manusia. Perkembangan pesat di bidang teknologi informasi dan komunikasi dewasa ini, dilandasi oleh perkembangan matematika dibidang teori bilangan, aljabar, analisis, teori peluang dan matematika diskrit. Oleh karena itu, untuk dan memanfaatkan teknologi di masa depan diperlukan penguasaan matematika yang kuat sejak dini (Mulbar, 2008), maka kita perlu menyadari pentingnya penguasaan matematika.

Mata pelajaran matematika merupakan mata pelajaran yang wajib bagi siswa pada jenjang pendidikan dasar dan menengah. Mata pelajaran yang diberikan pada jenjang sekolah dasar dan menengah dipillih berdasarkan pada pentingnya pendidikan, serta pentingnya untuk menguasai dan memanfaatkan teknologi di masa depan. Mata pelajaran matematika berguna untuk membekali siswa dengan kemampuan berpikir logis, analisis, sistematis, kreatif, dan kritis serta mampu bekerja sama (Mulbar, 2008). Kemampuan tersebut merupakan kompetensi yang diperlukan oleh siswa agar dapat memiliki kemampuan memperoleh, mengelolah dan memanfaatkan informasi untuk bertahan hidup pada keadaan yang selalu berubah, tidak pasti dan kompetitif.
Oleh sebab itu, dunia pendidikan sekarang dituntut untuk senantiasa melakukan inovasi dalam pembelajaran, khususnya pembelajaran matematika dalam berbagai aspek, mulai dari visi, misi, tujuan, program, metode, teknologi, proses, sampai evaluasi. Bagi seorang pendidik, khususnya pada mata pelajaran matematika pemilihan model pembelajaran hendaknya dilakukan secara cermat, agar pilihan itu tepat atau relevan dengan berbagai aspek pembelajaran yang lain, efisien dan menarik. Karena matematika memiliki karakteristik, dan objek dasar yang dipelajari dalam matematika adalah abstrak. Objek-objek dasar itu meliputi : (1) fakta, (2) konsep, (3) operasi atau relasi dan (4) prinsip (Soedjadi, 2000).

Setiap siswa mempunyai kemampuan berpikir yang berbeda satu dengan lainnya. Kemampuan berpikir yang dipandang paling rendah adalah kemampuan mengingat. Pengembangan proses berpikir siswa dapat dilakukan melalui proses pembelajaran yang dirancang dan dilaksanakan dengan baik. Proses pembelajaran dapat diartikan sebagai proses pengembangan potensi siswa, termasuk potensi berpikirnya.

Potensi berpikir mengacu kepada kemampuan-kemampuan intelektual, dan kecerdasan yang akan di capai seorang siswa. Domain kognitif oleh Bloom (dalam Soedjadi, 2000) dibedakan atas 6 kategori, yaitu : (1) 
ingatan, (2) pemahaman, (3) aplikasi, (4) analisis, (5) sintesis, dan (6) evaluasi. Untuk mencapai keberhasilan dalam suatu pembelajaran yang dilihat pertama dari segi domain kognitif adalah kemampuan siswa dalam mengingat informasi yang diterimanya.

Bagaimana suatu informasi dapat dengan mudah diingat oleh siswa, informasi yang diterima tersebut dapat bertahan lama dalam ingatannya, maka suatu informasi tersebut harus bermakna bagi siswa. Pemindahan informasi dari ingatan jangka pendek ke ingatan jangka pajang terjadi apabila informasi tersebut memiliki makna (Robert. et al, 2008) (memory) adalah penyimpanan informasi di setiap waktu, yang melibatkan pengkodean, penyimpanan, dan pemanggilan kembali. Dalam proses pengkodeaan informasi kemampuan mengingat seseorang tidak hanya pada pemprosesan yang mendalam atau bermakna, tetapi seseorang dapat memiliki ingatan yang baik ketika seseorang tersebut melibatkan elaborasi dalam proses pengkodeannya. Elaborasi adalah luasnya pemprosesan informasi yang terlibat dalam pengkodean (Santrock, 2011).

Ketika seseorang belajar matematika berarti seseorang tersebut belajar dengan abstrak. Nurhasanah (2010) menyatakan bahwa abstraksi merupakan proses yang mengantarkan siswa melakukan juga mengalami kegiatan-kegiatan yang pada akhirnya membentuk konsep-konsep yang abstrak. Ketiga definisi tersebut menyatakan bahwa abstraksi merupakan proses atau aktivitas yang dilakukan untuk mendapatkan pengertian dan pembentukan konsep-konsep dasar matematika melalui penyaringan terhadap gejala atau peristiwa terkait sesuatu yang abstrak.

Kemampuan berpikir abstrak setiap individu berbeda-beda. Hal ini akan berpengaruh terhadap proses pembelajaran yang akan dilakukan. Menentukan tingkat berpikir abstrak dapat menggunakan alat test psikologi. Melalui pengetahuan tentang kemampuan berpikir abstrak siswa, diharapkan dapat dipilihkan strategi pembelajaran yang tepat

Menurut penjelasan Bruner yang dikutip oleh Widada (2003), proses untuk mencapai matematika secara struktural harus melalui suatu proses belajar yang meliputi tiga level yaitu enaktif, ikonik, dan simbolik. Dari tiga level yang ada perpindahan yang harus diperhatikan adalah dari level ikonik ke simbolik. Hal ini dikarenakan simbol memiliki sifat abstrak dan kosong dari arti.

Apabila dilakukan dengan tidak seksama maka proses perpindahan level tersebut tidak bermakna. Untuk itu, gradualitas dua level tersebut tidak bisa serta merta dari ikonik langsung ke simbolik. Harus ada level baru dalam 
transisi antara ikonik dan simbolik. Ini berdasarkan prinsip notasi bahwa pencapaian suatu konsep dan penggunaan simbol-simbol matematika harus secara bertahap mulai dari yang sederhana yang secara kognitif dapat dipahami baru kemudian perlahan-lahan meningkat ke yang lebih komplek.

Menurut Easly (Putra, 2010) ada empat level abstraksi yang terpadu secara fungsional. Level pertama dari proses abstraksi adalah level ObjekObjek Fisik. Objek-objek fisik meliputi manipulasi objek dan penemuan sifat objek itu sendiri. Level kedua adalah Model Teoritik, meliputi representasi objek-objek fisik atau fenomena yang disesuaikan dengan sifat-sifat atau atribut dari objeknya. Level ketiga yakni Bahasa Matematika, meliputi pertanyaan-pertanyaan yang terkait dengan objek-objek matematika. Level yang keempat adalah Teori-Teori Inferensi yang meliputi meta-bahasa dan menemukan pernyataan-pernyataan.

Ishida

(Widada,

mengklasifikan sistem representasi yaitu; 1) Model realistik yaitu representasi dengan situasi dunia nyata atau realistic; 2) Model manipulatif yaitu representasi dengan benda-benda manipulative; 3) Model gambar, yaitu representasi dengan gambar-gambar; 4) Model bahasa, yaitu representasi dengan bahasa sehari-hari; dan 5) Model simbolik, yakni representasi dengan simbol matematika.
Terlihat bahwa Ishida lebih menekankan pada sistem representasi yang merupakan suatu landasan untuk menentukan level abstraksi.

Budiarto (2007) mengutip teori Bruner yang menyatakan bahwa Model Level Abstraksi (MLA) terdiri dari level 0 : objek-objek konkret, level 1: modelmodel semi konkret, level 2: modelmodel teoritik, level 3: bahasa dalam domain contoh, level 4: bahasa matematika, dan level 5: model inferensi.

Berkaitan dengan hal itu, dalam proses abstraksi konsep dan prinsip matematika seorang siswa harus mampu menghubungkan materi yang telah diterimanya supaya informasi yang baru diterimanya dapat tersimpan baik di memori jangka panjang. Prinsip dan konsep matematika yang dipelajari seorang siswa dari sekolah dasar sampai dengan sekolah menengah selalu bersifat kesinambungan, seperti materi dimensi dua yang dipelajari siswa tingkat menengah, itu merupakan kesinambungan dari pembelajaran sudut dan segitiga yang mereka terima waktu sekolah dasar.

Kemampuan berpikir abstrak akan materi ruang dimensi dua tidak terlepas dari pengetahuan tentang konsep ruang dimensi dua itu sendiri karena berpikir memerlukan kemampuan untuk membayangkan atau menggambarkan benda dan peristiwa yang secara fisik tidak selalu ada. Siswa yang memiliki 
kemampuan berpikir abstrak baik akan dapat mudah memahami konsep-konsep abstrak dengan baik. Kemampuan berpikir abstrak tak lain merupakan kemampuan menemukan pemecahan masalah tanpa hadirnya objek permasalahan itu secara nyata.

Ruang dimensi dua merupakan salah satu materi yang cukup banyak terapannya dalam kehidupan seharihari, dan ruang dimensi dua juga merupakan materi pengantar pagi seorang siswa sekolah kejuruan dalam memahami materi kejuruan. Matematika yang di pelajari siswa dari tingkat sekolah dasar sampai dengan nanti di perguruan tinggi selalu berkesinambungan, maka dari itu seorang siswa harus mampu menghubungkan informasi yang telah ada di dalam memorinya dengan informasi yang baru di terimanya, agar tujuan dari pembelajaran dapat tercapai dengan baik.

Tetapi pada kenyataannya, kebanyakan siswa memiliki kelemahan dalam mengingat dan menghubungkan konsep dan prinsip matematika yang telah dipelajarinya. Bahkan sangat sering terjadi pada saat proses pembelajaran siswa mengaku telah memahami dan telah dapat menyelesaikan soal-soal yang diberikan, namun jika konsep dan prinsip matematika itu di tanyakan lagi pada hari berikutnya siswa tidak dapat mengingatnya dengan baik, apalagi jika materi tersebut diterima siswa beberapa tahun yang silam.

Oleh karena itu pembelajaran matematika di tingkat menengah sering mengalami kesulitan, bahkan guru harus mengulang kembali konsep-konsep matematika di sekolah dasar. Hal ini karena kurangnya kemampuan siswa dalam mengingat dan kurangnya kemampuan siswa dalam menghubungkan informasi baru dengan informasi yang telah ada di dalam memori.

Tujuan penelitian ini adalah untuk mendeskripsikan model elaborasi kognitif siswa dalam proses abstraksi konsep dan prinsip matematika ruang dimensi dua di Kelas XI Teknik Las SMKN 1 Curup.

\section{METODE PENELITIAN}

Jenis penelitian ini adalah penelitian deskriptif kualitatif karena penelitian ini digunakan untuk mengetahui model elaborasi kognitif siswa dalam proses abstraksi prinsip dan konsep matematika ruang dimensi dua. Penelitian ini dilaksanakan di kelas XI Teknik Las SMKN 1 Curup. Subjek penelitian ini adalah siswa kelas XI Teknik Las SMKN 1 Curup. Teknik pengumpulan data dalam penelitian ini berupa data tentang hasil tes kemampuan siswa dan wawancara. Data tersebut digunakan untuk menentukan model elaborasi kognitif siswa dalam proses abstraksi prinsip dan konsep 
matematika ruang dimensi dua. Sedangkan analisis data yang dilakukan peneliti melalui tiga tahap, yaitu tahap reduksi data, penyajian data dan penarikan kesimpulan.

\section{HASIL PENELITIAN}

Dalam menentukan subjek penelitian, peneliti memberikan tes kemampuan kepada siswa kelas XI Teknik Las SMKN 1 Curup tahun pelajaran 2013/2014 yang berjumlah 32 siswa. Tes kemampuan tersebut dilaksanakan pada hari sabtu tanggal 18 oktober 2014 dengan menggunakan instrumen tes kemampuan siswa dan diikuti oleh 31 siswa. Tes dilaksanakan dari pukul 09.00 - 10.30 WIB dengan menggunakan instrumen tes yang telah divalidasi.

Berdasarkan hasil tes kemampuan siswa, maka di peroleh 20 siswa sebagai calon subjek penelitian yang akan dikonsultasikan dengan guru matematika kelas tersebut untuk menentukan subjek penelitian, maka diperoleh subjek penelitian. Adapun pembahasan dari setiap subjek sebagai berikut :

\section{Subjek S01}

Fase Recognizing, hal-hal yang dapat disimpulkan dari subjek S01 pada Fase ini adalah: 1) Subjek dapat mengenal objek-objek dari ruang dimensi dua; 2) Subjek dapat menentukan bangun yang merupakan bangun ruang dimensi dua dan bukan bangun ruang dimensi dua; 3) Subjek dapat memukan konsep yang ada pada ruang dimensi dua; 4) Subjek dapat menemukan prinsip yang ada pada bangun ruang dimensi dua dengan cara mengingat materi yang pernah dipelajarinya mengenai ruang dimensi dua dan menganalisis objek-objek ruang dimensi dua yang diberikan; 5) Subjek dapat mempresentasikan konsep dari ruang dimensi dua; 6) Subjek dapat mempresentasikan prinsip dari ruang dimensi dua dengan bahasanya sendiri, baik itu secara lisan dan tulisan yaitu dengan cara menganalisa objek yang diberikan dan mengingat materi yang telah di pelajari.

Fase Building With, hal- hal yang dapat disimpulkan dari subjek S01 pada fase ini adalah: 1) Subjek dapat menemukan hubungan-hubungan konsep yang ada pada bangun ruang dimensi dua, walaupun subjek harus berulang kali memperhatikan objek yang diberikan; 2) ubjek dapat menentukan hubungan- hubungan dari ruang dimensi dua, terbukti saat subjek tidak mampu mengingat rumus luas dari trapesium subjek tetap dapat mencarai luas trapesium tersebut dengan mencari luas segi empat dan menambahnya dengan luas segitiga yang apa pada trapesium tersebut dan saat menentukan hubungan- hubungan tersebut subjek harus membuat sketsa dari objek- objek tersebut.. 
Fase Contracting, hal-hal yang dapat disimpulkan dari subjek S01 pada Fase ini adalah: 1) Subjek dapat menggabungkan prinsip dan konsep dari bangun ruang dimensi dua; 2) Subjek dapat menerapkan prinsip dan konsep dari ruang dimensi dua dengan baik; 3) Subjek dapat membuat kesimpulan dari hasil pekerjaannya.

\section{Subjek S02}

Fase Recognizing, hal-hal yang dapat disimpulkan dari subjek S02 pada Fase ini adalah: 1) Subjek dapat mengenal objek-objek dari ruang dimensi dua; 2) Subjek dapat menentukan bangun yang merupakan bangun ruang dimensi dua dan bukan bangun ruang dimensi dua; 3) Subjek dapat menemukan konsep yang ada pada ruang dimensi dua; 4) Subjek dapat menemukan prinsip yang ada pada bangun ruang dimensi dua; 5) Subjek dapat mempresentasikan konsep dari ruang dimensi dua; 6) Subjek dapat mempresentasikan prinsip dari ruang dimensi dua dengan bahasanya sendiri

Fase Building With, hal- hal yang dapat disimpulkan dari subjek S02 pada fase ini adalah: 1) Subjek dapat menemukan hubungan-hubungan konsep yang ada pada bangun ruang dimensi dua; 2) Subjek dapat menentukan hubungan- hubungan dari ruang dimensi dua.

Fase Contracting, hal-hal yang dapat disimpulkan dari subjek S02 pada
Fase ini adalah :1) Subjek dapat menggabungkan prinsip dan konsep dari bangun ruang dimensi dua; 2) Subjek dapat menerapkan prinsip dan konsep dari ruang dimensi dua dengan baik. 3)Subjek dapat membuat kesimpulan dari hasil pekerjaannya.

\section{Subjek S03}

Fase Recognizing, hal-hal yang dapat disimpulkan dari subjek S03 pada fase ini adalah: 1) Subjek mengenal objek-objek ruang dimensi dua; 2) Subjek dapat menentukan objek ruang dimensi dua dan bukan ruang dimensi dua; 3) Subjek kurang mampu memukan konsep dan prinsip yang ada pada bangun ruang dimensi dua; 4) Subjek kurang mampu mempresentasikan konsep dan prinsip dari bangun ruang dimensi dua, dan subjek mengakui hal tersebut.

Fase Building With, hal- hal yang dapat disimpulkan dari subjek S03 pada fase ini adalah: 1) Subjek kurang mampu menemukan hubunganhubungan konsep dan prinsip ruang dimensi dua

Fase Constracting, hal-hal yang dapat disimpulkan dari subjek S03 pada fase ini adalah: 1) Subjek kurang mampu menghubungkan pengetahuannya; 2) Subjek dapat menggabungkan prinsip-prinsip yang ada pada konsep ruang dimensi dua; 3) Subjek mampu menerapkan konsep dan prinsip ruang dimensi dua. 


\section{Subjek S04}

Fase Recognizing, hal- hal yang dapat disimpulkan dari subjek S04 pada fase ini adalah: 1) Subjek mengenal objek- objek ruang dimensi dua, terbukti subjek dapat memberi nama dari bangun ruang dimensi dua dengan benar; 2) Subjek dapat menentukan objek yang merupakan bangun ruang dimensi dua dan bukan ruang dimensi dua; 3) Subjek dapat menentukan konsep yang ada dari bangun ruang dimensi dua; 4) Subjek dapat menemukan prinsip yang ada pada bangun ruang dimensi dua; 5) Subjek mampu mempresentasikan konsep- dan prinsip dari bangun ruang dimensi dua.

Fase Building With, hal- hal yang dapat disimpulkan dari subjek S04 pada fase ini adalah: 1) Subjek mampu menghubungkan pengetahuannya, sehingga subjek mampu menemukan hubungan-hubungan konsep dan prinsip dari bangun ruang dimensi dua.

Fase Constracting, hal-hal yang dapat disimpulkan dari subjek S04 pada fase ini adalah: 1) Subjek dapat menggabungkan konsep dan prinsip dari bangun ruang dimensi dua; 2) Subjek dapat menerapkan konsep dan prinsip dari bangun ruang dimensi dua dengan baik; 3) Subjek dapat membuat kesimpulan dari hasil pekerjaannya.

\section{Subjek S05}

Fase Recognizing, hal- hal yang dapat disimpulkan dari subjek S05 pada fase ini adalah: 1) Subjek dapat mengenal objek-objek dari ruang dimensi dua; 2) Subjek dapat menentukan bangun yang merupakan bangun ruang dimensi dua dan bukan bangun ruang dimensi dua; 3) Subjek dapat memukan konsep yang ada pada ruang dimensi dua; 4) Subjek dapat menemukan prinsip yang ada pada bangun ruang dimensi dua dengan cara mengingat materi yang pernah dipelajarinya mengenai ruang dimensi dua dan menganalisis objek-objek ruang dimensi dua yang diberikan; 5) Subjek dapat mempresentasikan konsep dari ruang dimensi dua; 6) Subjek dapat mempresentasikan prinsip dari ruang dimensi dua dengan bahasanya sendiri.

Fase Building With, hal- hal yang dapat disimpulkan dari subjek S05 pada fase ini adalah: 1) Subjek dapat menemukan hubungan-hubungan konsep yang ada pada bangun ruang dimensi dua; 2) Subjek dapat menentukan hubungan- hubungan dari ruang dimensi dua.

Fase Constracting, hal-hal yang dapat disimpulkan dari sujek S05 pada fase ini adalah : 1) Subjek dapat menggabungkan prinsip dan konsep dari bangun ruang dimensi dua; 2) Subjek dapat menerapkan prinsip dan konsep dari ruang dimensi dua dengan baik; 3 ) Subjek dapat membuat kesimpulan dari hasil pekerjaannya. 


\section{PEMBAHASAN}

Rekapitulasi hasil penelitian berdasarkan deskripsi model elaborasi kognitif siswa dalam proses abstraksi prinsip dan konsep matematika ruang dimensi dua yaitu sebagai berikut:

\section{Fase Recognizing}

1. Siswa mengenal dengan jelas bangun-bangun ruang dimensi dua, yaitu siswa dapat memberikan namanama bangun ruang dimensi dua dengan benar.

2. Siswa dapat memahami definisi bangun ruang dimensi dua dari gambar-gambar atau objek-objek ruang dimensi dua yang diberikan, dan berdasarkan informasi yang telah siswa peroleh sebelumnya. Dari gambar dan berdasarkan pemahaman tersebut siswa dapat menentukan objek-objek yang merupakan bangun ruang dimensi dua dan bukan bangun ruang dimensi dua.

3. Siswa mampu memahami konsep dari objek-objek ruang dimensi dua berdasarkan gambar-gambar yang diberikan.

4. Siswa dapat menemukan prinsip dari bangun - bangun ruang dimensi dua dengan menganalisis gambar gambar objek ruang dimensi dua, dan menghubungkan hasil analisis tersebut dengan informasi yang tersimpan dalam ingatan siswa.

5. Siswa dapat mempresentasikan konsep dan prinsip ruang dimensi dua sesuai dengan pemahaman yang dimiliki subjek sebelumnya.

\section{Fase Building With}

Siswa dapat menemukan hubungan-hubungan konsep dan prinsip dari bangun ruang dimensi dua dengan menganalisis gambar objek-objek bangun ruang dimensi dua.

\section{Fase Contracting}

1. Siswa mengetahui konsep-konsep apa yang akan digunakan, dan untuk mengetahui konsep tersebut siswa membayangkan dan membuat sketsa objek ruang dimensi dua dari permasalahan yang ada, dalam menyelesaikan permasalahan tersebut berhubungan dengan penggabungan prinsip-prinsip matematika yang ada dalam konsep tersebut, dan pengetahuan siswa tersebut sesuai dengan kemampuan sisiwa mengingat kembali konsep-konsep yang telah dimiliki sehingga mengasilkan suatu gagasan untuk menyelesaikan permasalahan yang ada.

2. Siswa mampu menggunakan konsep dan prinsip matematika dalam menyelesaikan permasalahan sehingga siswa mampu membuat kesimpulan dari hasil penyelesaian tersebut.

3. Siswa mampu menjelaskan atau memperesentasikan hasil pekerjaannya. 


\section{SIMPULAN}

Berdasarkan hasil penelitian dan pembahasan maka dapat disimpulkan jika; 1) Siswa mengenal dengan jelas bangun-bangun ruang dimensi dua, yaitu siswa dapat memberikan namanama bangun ruang dimensi dua dengan benar; 2) Siswa dapat memahami definisi bangun ruang dimensi dua dari gambar-gambar atau objek-objek ruang dimensi dua yang diberikan, dan berdasarkan informasi yang telah siswa peroleh sebelumnya. Dari gambar dan berdasarkan pemahaman tersebut siswa dapat menentukan objek-objek yang merupakan bangun ruang dimensi dua dan bukan bangun ruang dimensi dua; 3) Siswa mampu memahami konsep dari objek-objek ruang dimensi dua berdasarkan gambar-gambar yang diberikan; 4) Siswa dapat menemukan prinsip dari bangun - bangun ruang dimensi dua dengan menganalisis gambar -gambar objek ruang dimensi dua, dan menghubungkan hasil analisis tersebut dengan informasi yang tersimpan dalam ingatan siswa; 5) Siswa dapat mempresentasikan konsep dan prinsip ruang dimensi dua sesuai dengan pemahaman yang dimiliki subjek sebelumnya; 6) Siswa dapat menemukan hubungan-hubungan konsep dan prinsip dari bangun ruang dimensi dua dengan menganalisis gambar objek-objek bangun ruang dimensi dua; 7) Siswa mengetahui konsep-konsep apa yang akan digunakan, dan untuk mengetahui konsep tersebut siswa membayangkan dan membuat sketsa objek ruang dimensi dua dari permasalahan yang ada, dalam menyelesaikan permasalahan tersebut berhubungan dengan penggabungan prinsip-prinsip matematika yang ada dalam konsep tersebut, dan pengetahuan siswa tersebut sesuai dengan kemampuan sisiwa mengingat kembali konsepkonsep yang telah dimiliki sehingga mengasilkan suatu gagasan untuk menyelesaikan permasalahan yang ada; 8) Siswa mampu menggunakan konsep dan prinsip matematika dalam menyelesaikan permasalahan sehingga siswa mampu membuat kesimpulan dari hasil penyelesaian tersebut; 9) Siswa mampu menjelaskan atau memperesentasikan hasil pekerjaannya.

\section{DAFTAR PUSTAKA}

Putra, D., F. (2010). Deskripsi Proses Abstraksi Mahasiswa Pendidikan Matematika Dalam Memahami Konsep dan Prinsip Pada Teori Graph. Skripsi. Universitas Bengkulu.

Kimberly, O, R. (2008). Psikologi Kognitif. Jakarta: Erlangga

Mega T., B. (2007). Model Level Abstraksi (MLA) Suatu proses Abstraksi Tentang Operasi Pecahan. Proposal Disertasi. Universitas Negeri Surabaya 
Nurhasanah, F. (2010). Abstraksi Siswa SMP dalam Belajar Geometri melalui Penerapan Model Van Hiele dan Geometer's Sketchpad . Tesis pada FKIPUPI Bandung: Tidak diterbitkan. Tersedia :http://repository.upi.edu/tesisvie w.php?no_tesis $=1833$ diakses pada 11 April 2014.

Santrock. J., W. (2011). Psikologi Pendidikan. Jakarta: Selemba Hamka

Soedjadi. (2000). Kiat Pendidikan Di Indonesia. Jakarta.Dekdikbud

Mulbar, U. (2008). Metakognisi Siswa Dalam Menyelesaikan Masalah Pada Pembelajaran Matematika. Makalah Disajikan Dalam Seminar Nasional Pendidikan Matematika IAIN Surabaya.

Widada. (2003). Struktur Representasi Pengetahuan Mahasiswa tentang Permasalahan Grafik Fungsi dan Kekonvergenan Deret Tak Hingga pada Kalkulus. Disertasi S3 P. Matematika UNESA, Hasil Ujian Tertutup 11 April 2003. 